\title{
Physicochemical and Microbiological Quality of Selected Commercial and Traditional Honey in Klang Valley Market, Malaysia
}

\author{
Khadra, Y. M. ${ }^{1}$, Nurul Shafiqa Atikah, M. K. ${ }^{1}$, Nurul Nadia, A. A. ${ }^{1}$, Shukri, R. ${ }^{2}$, Nor- \\ Khaizura, M. A. R. ${ }^{*}$ \\ ${ }^{1}$ Department of Food Science, Faculty of Food Science and Technology, Universiti Putra Malaysia, 43400 \\ Serdang Selangor, Malaysia \\ ${ }^{2}$ Department of Food Technology, Faculty of Food Science and Technology, Universiti Putra Malaysia, 43400 \\ Serdang Selangor, Malaysia
}

Received 30 September 2017; accepted 3 April 2018; available online 1 August 2018

DOI: https://10.30880/jst.2018.10.02.012

\begin{abstract}
This study was intended to determine the physicochemical and microbiological quality of commercial and traditional honey in Klang Valley. Eleven honey samples from different origins were obtained and examined. Commercial honey samples were labelled as A, B, C, D, E and F and traditional honey samples consisted of Yemeni Sidr honey, Red Tualang honey, Black Tualang honey, Acacia honey and Fraser Hills Tualang honey. Physicochemical quality such as sugar content moisture content, water activity, $\mathrm{pH}$ and colour were measured. The $\mathrm{pH}$ value for commercial honey reached from $\mathrm{pH} 3.48$ to 3.97 while the $\mathrm{pH}$ value for traditional honey reached from 3.07 to 4.72 . The moisture content of commercial honey ranged from $17.53 \%$ to $18.93 \%$ compared to moisture content for traditional honey ranged from $18.03 \%$ to $20.67 \%$. The water activity for commercial and traditional honey was in the range 0.56 to $0.62 \mathrm{a}_{\mathrm{w}}$ and 0.52 to $0.62 \mathrm{a}_{\mathrm{w}}$, respectively. Total sugar content obtained for commercial honey varied from 79.27 to $81.73 \mathrm{~g} / \mathrm{mL}$ while total sugar content obtained for traditional honey were slightly higher, from 80 to 83.77 $\mathrm{g} / \mathrm{mL}$. Colour revealed that commercial honey, D, has the darkest colour compared to other honey $(* \mathrm{~L}=2.11 \pm 0.08, * \mathrm{a}=-0.02 \pm 0.21, * \mathrm{~b}=1.63 \pm 0.15)$. Standard plate count and yeast and mould were carried out to determined microbiological quality of honey. Generally, honey samples A, B, C, D and Acacia honey were considered safe, as no growth was detected on standard plate count. Less than $10 \mathrm{CFU} / \mathrm{g}$ was detected in Honey E, Black Tualang honey and Fraser Hills Tualang honey. There was no growth of yeast and mould count except for Red Tualang honey with not more than $10 \mathrm{CFU} / \mathrm{g}$. Results in this study are within the limits of standards and are comparable with previous reports on honey from various countries.
\end{abstract}

Keywords: Honey; physicochemical properties; microbiological quality.

\section{Introduction}

Honey is originated by bees (Apis mellifera) from the nectar of flowers. It has a very sweet taste and viscous syrup texture. Honey is teeming with excellent nutritional values and health benefit consequences [1]. This could be due to the presence of about 200 substances considered the essential part of traditional medicine. The chemical composition of honey is complex, consists of sugars, vitamins, minerals, proteins, flavonoids, enzymes phenolic acids, 5hydroxymethylfurfural (HMF) and volatile compounds [2]. These compositions can be influenced by different factors such as floral types, geographical areaand entomological source [3]. Honey provides numerous phenolic compounds, which are excellent sources of antioxidant. Therefore, it has the capability of posing antiseptic and antibacterial properties. These properties could inhibit the growth and infections of certain bacteria. As a traditional medicine, honey has been used for several purposes such as upset stomach, coughs, and sore throats. Rao, Krishnan, Salleh, and Gan (2016) have reported honey could treat gastrointestinal disorders [4]. In addition, honey is hygroscopic where it can drain out the moisture and dehydrate the bacteria. The low-level of $\mathrm{pH}$ and high sugar content also can impede the microbe's growth [5]. Furthermore, low moisture content could inhibits the formation of HMF from sucrose [3].

The quality and safety of honey is influence by the presence of microorganisms. Bacteria, molds, and yeast, e.g., Pseudomonas,

\footnotetext{
*Corresponding author: norkhaizura@upm.edu.my

2018 UTHM Publisher. All right reserved.

e-ISSN: 2600-7924/penerbit.uthm.edu.my/ojs/index.php/jst
} 
Psychrobacter, Acinetobacter, Bacillus, Clostridium, Corynebacterium, Micrococcus spp, Brochothrix, and Citrobacter are found in honey and honeycombs. The microorganisms in honey can be from bees, nectars and external sources, such as environmental conditions, handling, and storage [6]. Honey quality can be analyzed by different characteristics; the physical, chemical, microbiological and sensorial. The quality criteria of honey are referred in the regulatory standards (Codex Alimentarius Standard). Even though the quality of honey is already specified, the report of honey quality around central of Malaysia is still limited. Therefore, this study aims to analyze the physicochemical and microbiological quality of commercial and traditional honey available in Klang Valley market.

\section{Material and Method \\ 2.1 Honey}

Eleven honey used in this research were purchased from Klang Valley Market, Malaysia. They were six commercial honey, labeled as A, B, C, D, E, and F, and five traditional honey, namely as Yemeni Sidr honey, Red Tualang honey, Black Tualang honey, Acacia honey, and Fraser Hills Tualang honey.

\subsection{Physicochemical analysis}

\subsubsection{Determination of $\mathbf{p H}$}

Ten percent of the aqueous honey solution is used to test the $\mathrm{pH}$ by using a digital $\mathrm{pH}$ meter at $28 \pm 2^{\circ} \mathrm{C}$. The digital $\mathrm{pH}$ meter was calibrated first at 4.0 and 7.0 with standard buffer solutions [7].

\subsubsection{Determination of moisture content}

The refractometric method was used to analyze the moisture content by using Atago handheld refractometer at ambient temperature [8].

\subsubsection{Determination of water activity}

Water activity assay was conducted by Aqua lab water activity meter. Each sample was analyzed in three-panel determinations [9].

\subsubsection{Determination of honey colour}

The colour assessment of honey was carried out using a Hunter Lab, model D25 L optical sensor (Hunter Associates Reston, VA,
USA). A $10 \mathrm{~g}$ of diluted honey was placed into a cylindrical optical cell. $45 \mathrm{~mm}$ viewing aperture was using to measure the reflectance values [10].

\subsubsection{Determination of total sugar content}

Twenty-five percent (w/v) of honey solution was suspended in distilled water. A refractor metric method was used to determine the total sugar content for each honey sample. Ambient temperature required in measuring the refractive indices of honey samples by using an Atago handheld refractometer. Meanwhile, percentage of sucrose content was calculated per $\mathrm{g} / \mathrm{mL}$ honey [11].

\subsection{Microbiological analysis 2.3.1 Standard plate count}

Ten grams of honey was suspended in 90 $\mathrm{ml}$ of $0.1 \%$ phosphate buffer solution. A series of dilutions were then carried out and $0.1 \mathrm{ml}$ was spreaded on Plate Count Agar (PCA) (OXOID). The culture were incubated for $72 \mathrm{~h}$ at $37^{\circ} \mathrm{C}$.

\subsubsection{Yeast and mold count}

Ten grams of honey was suspended in 90 $\mathrm{ml}$ of $0.1 \%$ phosphate buffer solution. A series of dilutions were then carried out and $0.1 \mathrm{ml}$ was spreaded on Potato Dextrose Agar (PDA) (OXOID). The culture were incubated for 5 days at $25^{\circ} \mathrm{C}$.

\section{Result and Discussion \\ 3.1 Determination of $\mathbf{p H}$}

Acacia honey resulted as the most acidic honey with $\mathrm{pH} 3.07 \pm 0(\mathrm{p}<0.05)$ among all the honey types, (Table 1). Normally, highlevel acid of honey can induce the fermentation process of sugars into organic acids. However, Yemeni Sidr honey was slightly acidic ( $\mathrm{pH} 4.72 \pm 0.01)$. This study discovered that all the investigated honey samples were not exceeding the allowed limit of $\mathrm{pH}$, which then considered as an index of freshness. $\mathrm{pH}$ is an applicable indicator in determining any feasible microbial contamination [12]. It could be a significant factor in the preservation of honey because it can control the microbial spoilage and the shelf life of product [13]. Instinctively, most bacteria and moulds can grow in mildly alkaline and neutral conditions, respectively [14]. Meanwhile, yeasts required an acidic condition ( $\mathrm{pH}$ range of 4.0 to 4.5 ). The $\mathrm{pH}$ 
values of the honey samples were acidic $(\mathrm{pH}$ 3.07 to 4.72 ), which obey the recommended limits ( $\mathrm{pH} 3.4$-6.1) for fresh honey [15]. The $\mathrm{pH}$ values of Turkish, Spanish and Algerian honey were discovered to be in the range of 3.67 to $4.57,3.63$ to 5.01 and 3.49 to 4.53 , respectively [16]. Even though honey is considered to be acidic, the high sugar content masks the acidity in the honey taste. Naturally, honeyis dominated by formic acid and citric acid. However, it was recently discovered that gluconic acid is the predominant acid compound produced from bee secretions under the action of oxidase enzyme on glucose [17]. The high-level acid of honey is required due to its benefit in promoting the wound healing through the release of oxygen from hemoglobin [18].

\subsection{Determination of moisture content}

The analysis of moisture content is used to measure the water presence in honey, as it is a dominant parameter to determine honey quality. The moisture content must be within the limit $(\leq 20 \%)$ based on the international regulations. Various factors contributed to the water content in honey such as the degree of maturity reached in the hive, harvesting season and climatic factors [19].The moisture content of honey F and Yemeni Sidr honey samples shows a significant different, ( $p<0.05$ ). Honey $\mathrm{F}$ shows the lowest moisture content by $17.53 \% \pm 0.31$ and Yemeni Sidr honey shows the highest moisture content by $20.67 \% \pm 1.15$ (Table 1). The moisture content of honey from different origins shows varied differences, ranged from $13 \%$ to $29 \%$ [16]. The low moisture content in honey samples was indicating longer shelf life during storage, which facilitates a good storage ability and quality. It can be an important factor to resist fermentation and granulation during storage [20].

\subsection{Determination of water activity $\left(a_{w}\right)$}

The water activity $\left(a_{\mathrm{w}}\right)$ in honey can be a significant factor in determining the survival or growth of microorganisms. Normally, water activity levels of honey fall below 0.60.This study resulted, $\mathrm{a}_{\mathrm{w}}$ levels of the honey samples fall between 0.52 and 0.62 (Table 1). However, commercial honey labeled as C, F, and Fraser Hills Tualang honey had $\mathrm{a}_{\mathrm{w}}$ levels exceeding 0.60 , which may allocate a suitable medium for yeast growth. The water activity is a vital factor that controls the stability of food by impeding and restraining microbial growth. The shelf life of honey and growth of undesirable microflora, especially osmotolerant yeast can be influenced by the increasing of water activity. This is because the osmotolerant yeasts can grow at a lowlevel water activity of 0.60 [16]. Although osmolality plays a significant role in the antimicrobial activity of honey, yet, there are other factors in honey that also have a tremendous role in the antimicrobial effect of honey. Water condition in honey could be depended on factors such as source of nectar, the location of the flowers, the storage time, and preservation method [21]. The quality of honey is usually influenced by the water activity owing to its stability, viscosity, and crystallization [16]. For instance, in the crystallization process, water is set free by the formation of glucose monohydrate. Thus, it can lower the liquid concentration and increases the water activity.

\subsection{Determination of total sugar content}

The total sugar content is the sum of all monosaccharides, disaccharides and oligosaccharides. The total sugar content of the honey samples was ranging between 79.27 and $83.77 \mathrm{~g} / \mathrm{ml}$, which are slightly above the maximum limit $(\geq 60 \%)$ based on the European honey directive (Table 1). Yemeni Sidr honey was determined as the highest total sugar content (83.77 \pm 0.05$)$. Meanwhile, the reported sugar content of Algerian honey was in a range of 62.80 to $70.00 \mathrm{~g} / \mathrm{ml}$ [22]. High sugar content in honey samples may aid to low moisture content and high acidic nature, which hinder the emergence of HMF, mainly in glucose and fructose. Additionally, honey is hygroscopic, which can drain out the moisture and dehydrate the bacteria. The high sugar content can prevent and inhibit the growth of microbes, thus impede fermentation [2].

\subsection{Determination of colour}

In food product, colour is an essential attribute since it is perceived immediately by the consumers. The colour of the untreated honey depends on its botanical origins. Therefore, colouris crucial in the categorization of monofloral honey for commercial activities [20]. The maximum lightness among all honey samples isexhibited by Yemeni Sidr honey $(\mathrm{L}=13.02 \pm 0.57)$ while 
the minimum value is Honey $\mathrm{D}(\mathrm{L}=2.11 \pm 0.08)$ (Table 2). Redness was found to be highest for Honey F $(+a=7.59 \pm 0.15)$ and Honey B represented by a lowest value $(-\mathrm{a}=$ $1.59 \pm 0.11)$. Meanwhile, both Honey $\mathrm{E}$ and Yemeni Sidr were having the range of yellowness $(+b=12.16 \pm 0.38)$ and $(12.11 \pm 0.79)$ and the minimum value was in Honey $\mathrm{D}(+\mathrm{b}=$ $1.63 \pm 0.15)$. Colour data revealed that Honey D has the darkest colour compared to other honey $\quad(* \mathrm{~L}=2.11 \pm 0.08, \quad * \mathrm{a}=-0.02 \pm 0.21$, $* b=1.63 \pm 0.15)$. Fahim et al.(2014) reported that the darker colour of honey resembles the higher levels of polyphenols content [23]. It has been known that honey darkens with age. Furthermore, the various conservation methods and beekeeper's interference such as exposure to high temperatures or light and contact with metals might cause colour changes.

\subsection{Microbiological quality of honey}

The results of microbiological examination of the honey samples were shown in Table 3. Honey A, B, C and D demonstrated the absence of bacteria and mold growth due to the antimicrobial properties it possesses. The high osmotic pressure of honey due to its concentrated sugar solution contributes to the unsuitable condition for microbial growth [20]. Meanwhile, Honey E, Black Tualang honey, and Fraser Hills Tualang honey displayed microbial growth less than $10 \mathrm{CFU}$ /g. A study by Iurlina and Fritz (2005) reported the higher levels of microbial content in commercial honey samples for aerobic mesophiles counts were (average $244 \mathrm{CFU} / \mathrm{g}$ ) while mould and yeasts counts(average 34 $\mathrm{CFU} / \mathrm{g}$ ) [24]. The presences of moulds in this study might due to unhygienic practices during harvesting, packaging, andstore of the honey samples. Molds are known as xerophiles since they thrive in samples with low water contents between 16.2 to $17.0 \%$.

\subsection{Conclusion}

The physicochemical and microbiological quality of selected commercial honey $(\mathrm{A}-\mathrm{F})$ and traditional honey available in the random area of Klang Valley market was evaluated. In overall, the traditional honey have a higher range of $\mathrm{pH}$ value, moisture content, and total sugar content. The water activity of both commercial and traditional honey was in the same range. The microbiological quality of commercial and traditional honey present in this study had shown no growth of bacteria by standard plate count of honey A, B, C, D, and Acacia. Meanwhile, less than $10 \mathrm{CFU} / \mathrm{g}$ of bacterial growth were observed in E, Black Tualang, and Fraser Hills Tualang honey.

Table $1 \mathrm{pH}$ value, moisture content, water activity and total sugar content of selected honey

\begin{tabular}{|l|l|l|l|l|}
\hline Honey & $\mathbf{p H}$ & $\begin{array}{l}\text { Moisture } \\
\text { content }\end{array}$ & $\begin{array}{l}\text { Water } \\
\text { activity }\end{array}$ & $\begin{array}{l}\text { Total sugar } \\
\text { content }\end{array}$ \\
\hline Honey A & $3.72 \pm 0.01$ & $18.93 \pm 0.12$ & $0.56 \pm 0$ & $81.73 \pm 0.06$ \\
\hline Honey B & $3.48 \pm 0.01$ & $18.80 \pm 0.00$ & $0.59 \pm 0$ & $80.47 \pm 0.25$ \\
\hline Honey C & $3.75 \pm 0.01$ & $18.40 \pm 0.20$ & $0.61 \pm 0$ & $80.17 \pm 0.06$ \\
\hline Honey D & $3.48 \pm 0.01$ & $18.47 \pm 0.20$ & $0.60 \pm 0$ & $80.07 \pm 0.25$ \\
\hline Honey E & $3.97 \pm 0.02$ & $18.60 \pm 0.26$ & $0.57 \pm 0.01$ & $80.64 \pm 0.12$ \\
\hline Honey F & $3.61 \pm 0.02$ & $17.53 \pm 0.31$ & $0.62 \pm 0.04$ & $79.27 \pm 0.06$ \\
\hline Yemeni Sidr Honey & $4.72 \pm 0.01$ & $20.67 \pm 1.15$ & $0.54 \pm 0.03$ & $83.77 \pm 0.06$ \\
\hline Red Tualang Honey & $3.52 \pm 0.01$ & $19.47 \pm 0.31$ & $0.55 \pm 0$ & $82.20 \pm 0.1$ \\
\hline Black Tualang Honey & $3.56 \pm 0.01$ & $19.50 \pm 0.00$ & $0.52 \pm 0.01$ & $83.73 \pm 0.06$ \\
\hline Acacia Honey & $3.07 \pm 0$ & $18.80 \pm 0.00$ & $0.57 \pm 0.01$ & $80.47 \pm 0.31$ \\
\hline $\begin{array}{l}\text { Fraser Hills Tualang } \\
\text { Honey }\end{array}$ & $3.43 \pm 0.02$ & $18.03 \pm 0.06$ & $0.62 \pm 0.01$ & $80 \pm 0.1$ \\
\hline
\end{tabular}


Table 2 Colour value of selected honey

\begin{tabular}{|l|l|l|l|}
\hline Honey & $\mathbf{L}^{*}$ & $\mathbf{a}^{*}$ & $\mathbf{b}^{*}$ \\
\hline Honey A & $9.67 \pm 1.20 \mathrm{c}$ & $3.46 \pm 0.35 \mathrm{~b}$ & $10.26 \pm 0.43 \mathrm{~b}$ \\
\hline Honey B & $9.46 \pm 0.35 \mathrm{c}$ & $-1.59 \pm 0.11 \mathrm{f}$ & $7.98 \pm 0.28 \mathrm{c}$ \\
\hline Honey C & $3.41 \pm 0.15 \mathrm{ef}$ & $0.97 \pm 0.07 \mathrm{~d}$ & $2.26 \pm 0.24 \mathrm{ef}$ \\
\hline Honey D & $2.11 \pm 0.08 \mathrm{f}$ & $-0.02 \pm 0.21 \mathrm{e}$ & $1.63 \pm 0.15 \mathrm{f}$ \\
\hline Honey E & $11.22 \pm 0.33 \mathrm{~b}$ & $0.30 \pm 0.14 \mathrm{e}$ & $12.16 \pm 0.38 \mathrm{a}$ \\
\hline Honey F & $10.61 \pm 0.52 \mathrm{bc}$ & $7.59 \pm 0.15 \mathrm{a}$ & $9.68 \pm 0.36 \mathrm{~b}$ \\
\hline Yemeni Sidr Honey & $13.02 \pm 0.57 \mathrm{a}$ & $3.58 \pm 0.15 \mathrm{~b}$ & $12.11 \pm 0.79 \mathrm{a}$ \\
\hline Red Tualang Honey & $4.52 \pm 0.21 \mathrm{e}$ & $1.69 \pm 0.19 \mathrm{c}$ & $2.86 \pm 0.18 \mathrm{ef}$ \\
\hline Black Tualang Honey & $3.4 \pm 0.04 \mathrm{ef}$ & $1.75 \pm 0.14 \mathrm{c}$ & $3.38 \pm 0.1 \mathrm{e}$ \\
\hline Acacia Honey & $2.26 \pm 0 \mathrm{f}$ & $1.37 \pm 0.24 \mathrm{~cd}$ & $2.33 \pm 0.18 \mathrm{ef}$ \\
\hline $\begin{array}{l}\text { Fraser Hills Tualang } \\
\text { Honey }\end{array}$ & $6.97 \pm 0.51 \mathrm{~d}$ & $0.30 \pm 0.09 \mathrm{e}$ & $6.17 \pm 0.45 \mathrm{~d}$ \\
\hline
\end{tabular}

Table 3 Standard plate count and yeast and molds count of selected honey

\begin{tabular}{|l|l|l|}
\hline Honey & Standard Plate Count $(\mathrm{CFU} / \mathrm{g})$ & Yeast and Mould Count $(\mathrm{CFU} / \mathrm{g})$ \\
\hline Honey A & ND & ND \\
\hline Honey B & ND & ND \\
\hline Honey C & ND & ND \\
\hline Honey D & ND & ND \\
\hline Honey E & $<1.0 \times 10^{1}$ & ND \\
\hline Honey F & $2.1 \times 10^{3}$ & ND \\
\hline Yemeni Sidr Honey & $7.5 \times 10^{2}$ & ND \\
\hline Red Tualang Honey & $7.0 \times 10^{2}$ & $<1.0 \times 10^{1}$ \\
\hline Black Tualang Honey & $<1.0 \times 10^{1}$ & ND \\
\hline Acacia Honey & ND & ND \\
\hline $\begin{array}{l}\text { Fraser Hills Tualang } \\
\text { Honey }\end{array}$ & $<1.0 \times 10^{1}$ & ND \\
\hline
\end{tabular}

\section{References}

[1] Molan, P.C. (1992). "The Antibacterial Activity of Honey: 1. The Nature of the Antibacterial Activity" in Bee World, 73(1), pp. 5-28.

[2] Moniruzzaman, M., Khalil, M.I., Sulaiman, S.A., \& Gan, S.H. (2013). "Physicochemical and Antioxidant Properties of Malaysian Honeys Produced by Apiscerana, Apisdorsata and Apismellifera" in BMC Complementary and Alternative Medicine, 13(1), pp. 43.

[3] da Silva, P.M., Gauche, C., Gonzaga, L.V., Costa, A.C.O., \& Fett, R. (2016). "Honey: Chemical Composition, Stability and Authenticity" in Food Chemistry, 196, pp. 309-323.

[4] Rao, P.V., Krishnan, K.T., Salleh, N., \& Gan, S.H. (2016). "Biological and
Therapeutic Effects of Honey Produced by Honey Bees and Stingless Bees: A Comparative Review" in Revista Brasileira de Farmacognosia, 26(5), pp. 657-664.

[5] Moniruzzaman, M., Sulaiman, S.A., Azlan, S.A.M., \& Gan, S.H. (2013). "Two-year Variations of Phenolics, Flavonoids and Antioxidant Contents in Acacia Honey" in Molecules, 18(12), pp. 14694-14710.

[6] Al-Waili, N., Salom, K., Al-Ghamdi, A., \& Ansari, M.J. (2012). "Antibiotic, Pesticide, and Microbial Contaminants of Honey: Human Health Hazards" in The Scientific World Journal, pp. 1-9.

[7] Saliha, Ş., Demir, C., \& Borum, E. (2016). "Determination of Phenolic Compounds Profile in Chestnut and Floral Honeys and Their Antioxidant and 
Antimicrobial Activities" in Journal of Food Biochemistry, Vol. 42, pp. 1-12.

[8] Mandal, M.D., \& Mandal, S. (2011). "Honey: its Medicinal Property and Antibacterial Activity" in Asian Pacific Journal of Tropical Biomedicine, 1(2), pp. 154-160.

[9] Conti, M.E. (2000). "Lazio Region (Central Italy) Honeys: A Survey of Mineral Content and Typical Quality Parameters" in Food Control, 11(6), pp. 459-463.

[10] Shafiee, S., Minaei, S., Moghaddamcharkari, N., \& Barzegar, M. (2014). "Honey Characterization Using Computer Vision System and Artificial Neural Networks" in Food Chemistry, 159, pp. 143-150.

[11] Zamora, M.C., Chirife, J., \& Roldán, D. (2006). "On the Nature of the Relationship Between Water Activity and $\%$ Moisture in Honey" in Food Control, 17(8), pp. 64.

[12] Conti, M.E., Saccares, S., Cubadda, F., Cavallina, R., Tenoglio, C.A., \&Ciprotti, L. (1998). "Ilmielenel Lazio: Indaginesulcontenuto in Metalli in Tracce E Radionuclide" in La Rivista di Scienzadell'alimentazione, 27(2), pp. 107119.

[13] Olaitan, P.B., Adeleke, O.E., \& Iyabo, O.O. (2007). "Honey: a Reservoir for Microorganisms and an Inhibitory Agent for Microbes" in African health Sciences, 7(3).

[14] Khalil, M.I., Sulaiman, S.A., \&Gan, S.H. (2010). "High 5-hydroxymethylfurfural Concentrations are Found in Malaysian Honey Samples Stored for More Than One Year" in Food and Chemical Toxicology, 48(8), pp. 2388-2392.

[15] Terrab, A., Recamales, A.F., Hernanz, D., \& Heredia, F.J. (2004). "Characterisation of Spanish Thyme Honeys by Their Physicochemical Characteristics and Mineral Contents" in Food Chemistry, 88(4), pp. 537-542.
[16] Saxena, S., Gautam, S., \& Sharma, A. (2010). "Physical, Biochemical And Antioxidant Properties of Some Indian Honeys" in Food Chemistry, 118(2), pp. 391-397.

[17] Ball, D.W. (2007). "The Chemical Composition of Honey" in Journal of Chemical Education, 84(10), pp. 16431646.

[18] Buba, F., Gidado, A., \& Shugaba, A. (2013). "Physicochemical and Microbiological Properties of Honey From North East Nigeria" in Biochem Anal. Biochem, 2(142), pp. 1-7.

[19] Finola, M.S., Lasagno, M.C., \& Marioli, J.M. (2007). "Microbiological and Chemical Characterization of Honeys from Central Argentina" in Food Chemistry, 100(4), pp. 1649-1653.

[20] Helena Abramovic, Mojca Jamnik, Lina Burkan, Milica Kac (2008). "Water Activity and Water Content in Slovenian Honeys" in Food Control, 19(11), pp. 1086-1090.

[21] Missio, P., Gauche, C., Gonzaga, L.V., Carolina, A., \& Costa, O. (2016). "Honey: Chemical Composition, Stability and Authenticity" Food Chemistry, 196, pp. 309-323.

[22] Khalil, M.I., Moniruzzaman, M., Boukraâ, L., Benhanifia, M., Islam, M.A., Islam, M.N., \& Gan, S.H. (2012). "Physicochemical and Antioxidant Properties of Algerian honey" in Molecules, 17(9), pp. 11199-11215.

[23] Fahim, H., Dasti, J.I., Ali, I., Ahmed, S., \& Nadeem, M. (2014). "Physicochemical Analysis and Antimicrobial Potential of a Pisdorsata, a Pismelliferaand Z Iziphus Jujube Honey Samples from Pakistan" in Asian Pacific Journal of Tropical Biomedicine, 4(8), pp. 633-641.

[24] Iurlina, M.O., Fritz, R., (2005). "Characterization of Microorganisms in Argentinean Honeys from Different Sources" in International Journal of Food Microbiology 105(3), pp. 297-304. 